\title{
OCORRÊNCIA DE Cryptosporidium spp. NA SUINOCULTURA NO MUNICÍPIO DE PALOTINA, REGIÃO OESTE DO PARANÁ
}

(Occurrence of Cryptosporidium spp. on swine breeding in Palotina city, West region of Paraná)

André Luis Vriesman Beninca, Ana Paula Molinari Candeias, Géssica Niehues Becker, Ana Karollynna Gottems, Ana Júlia Dal Curtivo Back, Elisabete Takiuchi, Nelson Luis Mello Fernandes

Universidade Federal do Paraná, Palotina, Paraná, Brasil.

*Correspondência: drebeninca@gmail.com

RESUMO: A criptosporidiose é uma doença de caráter zoonótico causada pelo Cryptosporidium spp., um protozoário unicelular pertencente ao filo Apicomplexa, cosmopolita com grande capacidade de disseminação principalmente por meios hídricos, tem capacidade de se desenvolver na mucosa gástrica de animais vertebrados. Em suínos os sinais clínicos se apresentam principalmente em animais jovens como diarreia não hemorrágica, pelo caráter autolimitante animais adultos podem ser hospedeiros e eliminar os oocistos com as fezes, porém sem desenvolver sinais clínicos pelo desenvolvimento de imunocompetência. A via de transmissão é fecal-oral pela eliminação de oocistos com as fezes do hospedeiro que ao esporularem são aptos a infectar outros indivíduos seja via água ou alimentos contaminados. O ciclo biológico é monoxênico iniciando-se com a ingestão de oocistos esporulados presentes no ambiente, há ruptura do oocisto após o contato com os sais biliares a nível intestinal e assim liberam-se os trofozoítos, em seguida há a invasão dos enterócitos e diferenciação em merozoíto, seguido de um ciclo de auto infecção e uma gametogonia, diferenciando-se em macrogametócitos e microgametócito, a próxima etapa é uma reprodução sexuada com fecundação e liberação de oocistos não esporulados nas fezes do hospedeiro. Os casos de criptosporidiose estão associadas principalmente a períodos que os animais jovens são submetidos a estresse provocando imunossupressão, é comum se apresentar principalmente após a mudança de manejo, tal qual o desmame, contudo, sendo a criptosporidiose uma doença que tem a mesma apresentação clínica de enterites bacterianas supõe-se que sua ocorrência seja subestimada. Neste trabalho objetivouse determinar qual a ocorrência do Cryptosporidium spp. em suínos provenientes da suinocultura no município de Palotina, Oeste do Paraná. Foram selecionadas 18 fêmeas gestantes, 12 leitões e 29 fêmeas acompanhadas de leitão em granjas de ciclo completo. As amostras de fezes foram coletadas e acondicionadas individualmente, seguido de análise coproparasitológica de coloração Ziehl-Neelsen modificado conforme Ortolani (2000), onde foram classificadas qualitativamente mediante a observação de oocistos. Entre as categorias analisadas foram diagnosticados positivos 8 fêmeas (44,45\%), 4 leitões (33,34\%) e 8 fêmeas acompanhada de leitões pré desmame (27,6\%). Os resultados demonstram que há circulação ativa do protozoário nos sistemas de criação e que se perpetuam as proles subsequentes. A falta do diagnóstico adequado pode contribuir para a perpetuação do Cryptosporidium spp. nas granjas, uma vez que sinais clínicos entéricos são comumente associados a outros agentes infecciosos e são tratadas como tal pelo uso de antibióticos. Até o momento não há drogas específicas de uso veterinário para o tratamento da infecção pelo protozoário, logo a melhor maneira de controlar o agente é através de técnicas de manejo e boas práticas de criação. O controle da qualidade da água de bebida pelo monitoramento microbiológico ou pelo uso de água tratada, controle de dejetos provenientes da criação, manutenção do bem-estar dos animais para reduzir estresse, e consequentemente a minimizar imunossupressão do plantel são as melhores estratégias para reduzir a ocorrência da criptosporidiose.

Palavras-chave: criptosporidiose; protozoários; suínos; Ziehl-Neelsen; zoonoses.

Referência: ORTOLANI, E. L. Standardization of the modified Ziehl-Neelsen technique to stain oocysts of Cryptosporidium sp. Revista Brasileira de Parasitologia Veterinária, São Paulo, v. 9, n. 1, p. 29-31, 2000. 